\title{
ウンシュウミカンにおけるミカンキイロアザミウマの 寄生特性と被害の特徵
}

\author{
土屋雅利 ·外側正之 1 古橋嘉一・増井伸一
}

\section{静岡県柑㛢試験場}

\begin{abstract}
Infestation and Damage Caused by Western Flower Thrips (Frankliniella occidentalis Pergande) on Satsuma Mandarin (Citrus unshiu Marc.). Masatoshi Tsuchiya, Masayuki Togawa, ${ }^{2)}$ Kaichi Furuhashi and Shinichi Masul (Shizuoka Prefectural Citrus Experiment Station, Komagoenishi, Shimizu City 424, Japan). Jpn. J. Appl. Entomol. Zool. 39: 253-259 (1995)

Infestation and damage caused by Western Flower Thrips (Frankliniella occidentalis Pergande) on satsuma mandarin (Citrus unshiu MARC.) were examined in 1993. The number of thrips infesting flowers was greatest at the end of blossoming. More eggs hatched from the pistil, ovary and calyx than from the petal and stamen. Larva fed inside the calyx, and the damage resulted in young fruit rot as a result of fungal infection in the June rainy season. The economic damage caused by fruit rot can be minimized by fruit thinning. Adults could not survive on young fruits. Feeding on fruit was first observed when the color of peel oil spores changed to yellow and continued throughout the harvest period. Oviposition in the peel increased as the peel color changed from green to orange. Damaged fruit had many small spaces in the epidermis which appeared as whitish irregular dots. The color of frass on the peel was influenced by the color of the food peel. Shoot infestation was not observed.
\end{abstract}

Key words: infestation, damage, Frankliniella occidentalis, Citrus unshiu

緒 言

ミカンキイロアザミウマ Frankliniella occidentalis (PERGANDE) は, 我が国では 1990 年 6 月に千葉県内のシ クラメンで侵入害虫として発見され(福田ら, 1991), 静 岡県では 1992 年 6 月にハウスミカン, 露地キク等に発 生が確認された (土屋ら，1992)。ハウスミカンでは収穫 中の果実に被害と成虫及びふ化幼虫の寄生が確認され， 加害された果実の商品性は著しく低下する。しかし防除 対策が確立されていない(土屋・古橋，1993)ことや，本 種の寄主植物が 50 科 200 種以上 (BRYAN and SMITH, 1956)と多いため発生地域の拡大が懸念されている。

本種は, 1980 年代にヨーロッパ各地に花き等の施設 害虫として発生が拡大した経緯から，花き等での生態や 防除に関する報告は比較的多いが，カンキツに関する報 告は極めて少なく不明な点が多い。そこで著者らは，ウ ンシュウミカン (Citrus unshiu MARC.) における本種の要 防除時期を特定するため, 本種が多発する地域の施設並 びに露地栽培ウンシュウミカン園で本種の奇生性と被害
の特徴を調査した。併せて接種等により寄生性の再現試 験を実施したので，その結果を報告する。

本文に入るに先だち，本研究を実施するに当り種の同 定をして下さった工藤览博士 (静岡市), 試験ほ場を提供 された名倉気津治氏 (細江町), 調査で協力して下さった 和田靖彦, 縣茂樹両技術員 (細江町農協) ならびに経済連 西部, 中部柑㛢事業所の技術員諸氏に感謝の意を表す る。

材料および方法

\section{1. 部位別寄生消長と被害}

(1) 施設栽培における調査 (試験 1)

静岡県細江町気賀の施設栽培ウンシュウミカン園 (高 林早生, $10 \mathrm{a})$ 内に, 施設の南側側空と平行に $6 \mathrm{~m}$ 間隔 で定植された 3 樹を調査樹に設定し, 1993 年 5 月 7 日 から 7 月 15 日まで 1 週間ごとに各樹 30 果実を無作為 に抽出して寄生する成虫, 幼虫数を調查した。ちなみ に, 調查樹以外の収穫期間は 6 月 24 日から 7 月 16 日 までであった。また，7月21日から 10 月 21 日まで 1

1) 現在 静岡県中部病害虫防除所

2) Present address: Shizuoka Prefectural Central District Office of Plant Protection

1994 年 9 月 5 日受領 (Received 5 September 1994)

1995 年 3 月 15 日登載決定 (Accepted 15 March 1995) 
週間ごとに収穫後に発芽した新梢を各樹 30 新梢無作為 に抽出して寄生する成虫，幼虫数を調査した。さらに， 5 月 1 日に調査樹の間に 2 基の黄色平板粘着トラップ (粘着面積 $600 \mathrm{~cm}^{2}$ ) を設置して 10 月 21 日まで本種の捕 獲数を毎週調査した。なお，寄生調査時に被害の有無を 観察した。観察された被害は，暗視野装置付き実体顕微 鏡 (オリンパス JM-TR) でその特徵を詳細に観察した。

本種に影響を与えたと思われる防除剤の散布日，薬 剂，散布濃度はそれぞれ，5月 20 日にアセフェート水 和剂 1,000 倍, 6 月 3 日に DMTP 乳剤 1,000 倍, 6 月 16 日，21 日と 7 月 4 日に DDVP 乳剤 1,000 倍であっ た。

施設の温度調節のため，5月 7 日から 5 月 21 日まで は屋根の谷部のビニールを日中 $50 \sim 80 \mathrm{~cm}$ 巻き上げて 開け，5月 21 日から 6 月 23 日まではこれに加えて側 空を日中 $20 \sim 30 \mathrm{~cm}$, 収穫期間は側空を日中 $110 \sim 120$ $\mathrm{cm}$, 収穫後は側空を日中 $150 \mathrm{~cm}$ それぞれ巻き上げて 開け, 8 月 31 日以降は屋根のビニールを除去した。

(2) 露地栽培における調査 (試験 2)

試験 1 の施設に隣接し，これと平行に同じ間隔で定植 された露地ウンシュウミカン園 (高林早生, 10 a) の中央 の 3 樹を調査樹に設定した。 5 月 7 日 (開花開始前) か ら 10 月 21 日 (収穫開始日) まで 1 调間ごとに, 開花開 始前には花らいを, 開花開始後には花を, 花弁落下後に は幼果を各樹 30 個無作為に抽出して寄生虫数を調査し た。また，樹間に設置したトラップへの捕獲数も寄生虫 数調査日に調査した。さらに, 試験 1 と同様に寄生調査 時に観察された被害を検鏡調査した。

本種に影響を与えたと思われる防除剤の散布日，薬 剂, 散布濃度はそれぞれ，5月 21 日にアセフェート水 和剂 1,500 倍, 8 月 11 日にアセフェート水和剂 1,500 倍とマンゼブ水和剂 500 倍の混用散布, 9 月 15 日にア セフェート水和剂 1,500 倍とチアジアジン水和剤 800 倍 の混用散布であった。

2. 花や幼果からの幼虫ふ化数 (試験 3)

試験 2 のほ場から, 花および幼果を 5 月 20 日から 7 月 8 日までに 6 回採取して通気網付きポリエチレン製 容器に入れ， $27^{\circ} \mathrm{C}$ で 7 日間保温してふ化した幼虫数を 計数した。この場合，雌ずいの柱頭が脱落した子房を幼 果とした。

\section{3. 着色程度の異なる果実上でのふ化幼虫数とふ化痕 数の差異 (試験 4)}

試験 1 の施設及びこれに隣接した収穫予定日が約 1 か 月遅い施設栽培ほ場 (興津早生, $8 \mathrm{a}$ ) から, 本種の被害果
を 5 月 13 日，6月16日及び 6 月 24 日に採取し，空気 で膨らませたポリエチレン袋 (厚さ $0.03 \mathrm{~mm}, 12 \times 23 \mathrm{~cm}$ )

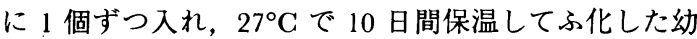
虫数を調査した。さらに果こうから果頂にかけて果面を 4 層 (果こう部の果こう側, 同じく赤道側, 果頂部の赤 道側，同じく果頂側）に区分してレザーで剥皮し，試験 1 と同じ実体顕微鏡でふ化痕数を調査した。なお，保温 中は袋内を毎日 1 回換気した。また，果実の着色程度は 完全着色を 10 分, 未着色を 0 分として着色面積によっ て 11 段階に区分した。

本種に影響があったと思われる薬剂の散布日，薬剂， 散布濃度はそれぞれ，6月 6 日にアセフェート水和剂 1,000 倍, 6 月 16 日に DDVP 乳剤 1,000 倍である。こ のうち，6月 16 日は 2 施設とも果実採取後に散布し た。

施設の温度調節のため，5月 7 日から 6 月 3 日まで は屋根の谷部のビニールを日中 $50 \sim 80 \mathrm{~cm}$ 巻き上げて 開け，6月 3 日から 7 月 25 日まではこれに加えて側空 を日中 $20 〜 30 \mathrm{~cm}$ 巻き上げて開けた。

4. ウンシュウ幼果に放飼した成虫の生存と加害 (試 験 5)

7 月 8 日に, 当場内の無農薬栽培ほ場の杉山温州の 幼果ならびにシキキツ (Citrus madurensis LouR.) の完熟果 を採取し，杉山温州単独およびこれとシキキツを同時に 入れた容器にハウスミカンから採取した本種成虫を放飼 し，6日後まで生虫数を調査した後，果皮の攝食痕の有 無とふ化痕数を試験 1 と同様検鏡調査した。

\section{5. 幼虫接種による幼果被害の再現 (試験 6)}

6 月 21 日 (梅雨期の雨天日) に当場内の無農薬栽培ほ 場から杉山温州の幼果 6 果を採取し，そのまま蓋に網の 付いた無色のプラスチック製容器 (直径 $10 \mathrm{~cm}$, 高さ 8 $\mathrm{cm})$ に果頂を上にして各容器 1 果ずつ収容した。この うち 3 果にはハウスミカンの熟果で飼育した 2 齢幼虫 を 1 果に 1 頭ずつ接種し, 残り 3 果は無接種として, 接種後 7 日間被害の発現を観察した。また，7月19日 (梅雨明け後の晴天日) に同様に接種し，7日間被害の発 現を観察した後，がくと幼果をレザーで切り離し，実体 顕微鏡でがくの表面と果皮の揌食痕および虫䔬を観察し た。

\section{6. 幼果の腐敗原因となった菌 (試験 7)}

6 月 24 日に試験 2 のほ場から，がくを中心に果面が 直径 $10 \mathrm{~mm}$ 程度の大きさに褐変している果実 20 個を 採取した。各果実の表面を水洗し滅菌ろ紙で水分を吸い 取った後, 健全部と変色部との境を 1 辺 $5 \mathrm{~mm}$ の切片 


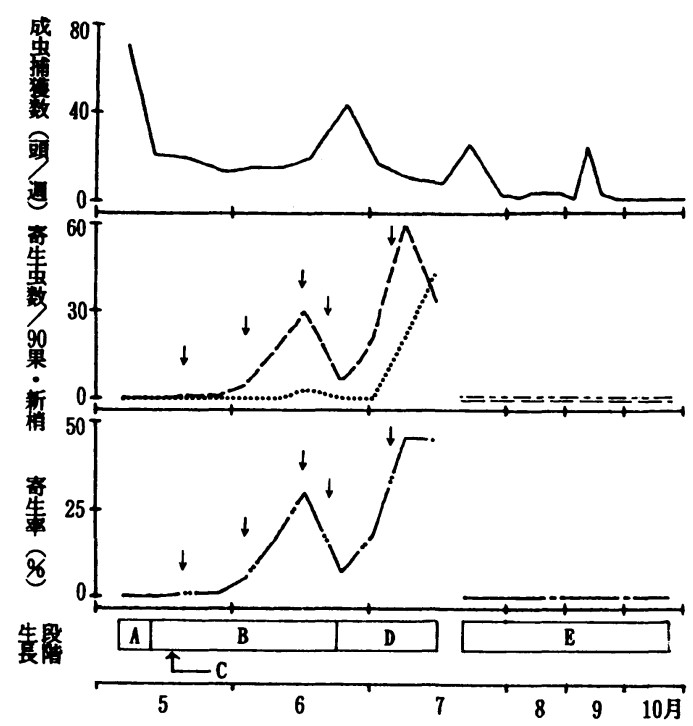

第 1 図 施設栽培ウンシュウミカン園でのトラップ捕獲数 と寄生虫数ならびに寄生率の変化. 一一：成虫捕獲 数, - - - 果実寄生成虫, ……果実寄生幼虫, 一新梢寄生成虫, - - - : 新梢寄生幼虫, - - - : 寄 生果率, - - - : 寄生新梢率, $\downarrow$ : 防除刘散布日, A 幼果期， B: 果実着色期， C: 果実の油胞が黄色になる 時期, D: 果実成熟期, E: 新梢伸長期.

とし，70\%エタノール溶液，次いで， $2 \%$ 次亜塩素酸ナ トリウム溶液で表面殺菌し滅菌蒸留水で洗浄後, PDA 培地 (ジャガイモ $200 \mathrm{~g}$, デキストロース $20 \mathrm{~g}$, 寒天 $15 \mathrm{~g}$, 蒸留水 $1000 \mathrm{ml})$ に置床し, $25^{\circ} \mathrm{C}$ で 5 日間培養して, 生育した菌の種類を徳永 (1984) により同定した。

\section{結果}

\section{1. 部位別寄生消長と被害}

(1) 施設栽培における結果

施設内でのトラップ捕獲数, 樹体上での虫の発生数及 び寄生率の変化を第 1 図に示した。トラップ捕獲数は, 調査開始時の 5 月上旬と 6 月下旬に多く，その後 7 月 下旬と 9 月中旬にピークが認められた。成虫の果実寄生 は，5月中旬 (果実の油胞が黄色になった時期) から認め られ始め, 収穫が終るまで続いた。果実上の成虫寄生数 と寄生率はほほ同調して変化し，5月中旬から次第に増 加して 6 月中旬をピークに減少した後，収穫を開始した 6 月下旬以降は再び増加し，7月上旬をピークに減少し た。果実の着色の進んだ 6 月中旬以降の果実上の成虫寄 生数と寄生率の変動には, トラップ捕獲数の増減と逆の 変化が認められた。幼虫の果実寄生は 6 月中旬から認め られ始め, この時期は成虫寄生数が増加しても幼虫数は

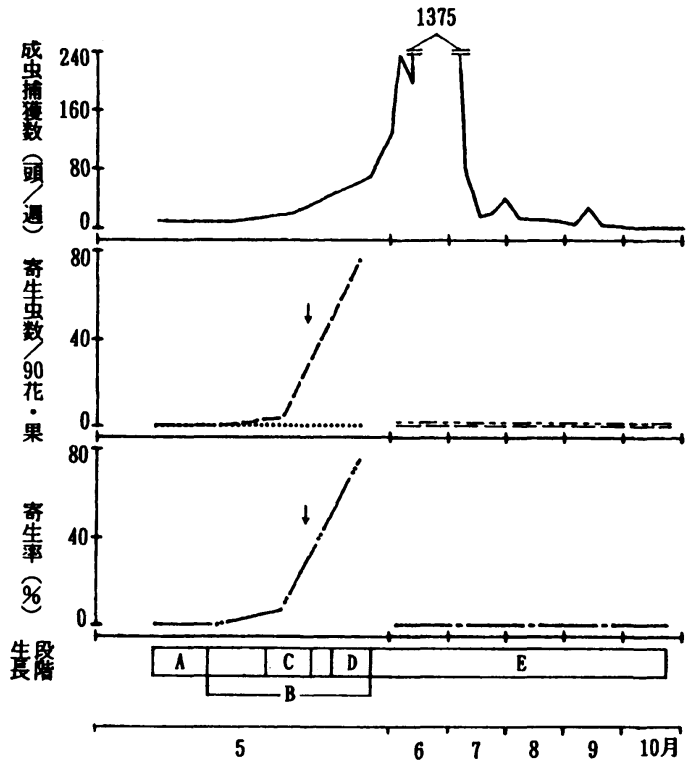

第 2 図 露地栽培ウンシュウミカン園でのトラップ捕獲数 と寄生虫数ならびに寄生率の変化. 一：成虫捕獲 数, - - . : 花寄生成虫, ……花寄生幼虫, 一果実寄生成虫, - - - : 果実寄生幼虫, 一…：寄 生花率, - - - : 寄生果率, $\downarrow$ : 防除剤散布日, A 開花開始前， B: 開花期， C: 開花盛期，D: 開花終期, $\mathrm{E}$ : 幼果期.

大きく変化しなかったが，7月には成虫数の増加に伴っ て幼虫数が次第に増加し，7月上旬に成虫数が減少して も幼虫数はさらに増加した。また，果実の収穫後，7月 中旬から伸長した新梢は次第に硬化していったが，この 新梢への寄生及び被害は，トラップ捕獲数の多少に関わ らず全期間認められなかった。

果実の被害は，果実の油胞が黄化した時期から認めら れた。被害は初め散在する白いカスリ状の斑点が現れる が, 果皮の切片を暗視野装置付き実体顕微鏡 (40 倍) で 観察した結果，これは果皮の表層にできた微細な空洞 (摂食痕)の集合であった。この付近には初め濃緑色の䔬 が付着していたが，果実の着色が進むと虫䔬の色は淡黄 色に変わった。なお，施設内に散布された薬剂の本種の 発生および被害への影響は判然としなかった。

(2) 露地栽培における結果

露地のトラップ捕獲数, 樹体上での虫の発生数及び寄 生率の変化を第 2 図に示した。トラップ捕獲数は, 施設 の側空を開く 5 月中旬までは露地では少なく，施設の側 空を開いた 5 月下旬以後は, 施設内と露地のピークの変 化はほほ一致し，総捕獲数は施設内より露地で多かっ 
第 1 表 花および幼果からのふ化幼虫数

\begin{tabular}{|c|c|c|c|c|c|c|c|c|}
\hline \multirow{2}{*}{ 採取日 } & \multirow{2}{*}{ 作物の状態 } & \multirow{2}{*}{$\begin{array}{l}\text { 調査 } \\
\text { 部位 }\end{array}$} & \multirow{2}{*}{ 調査数 } & \multirow{2}{*}{$\begin{array}{c}\text { 子房径 } \\
(\mathrm{mm})\end{array}$} & \multicolumn{3}{|c|}{ s化幼虫数 } & \multirow{2}{*}{ 合計 } \\
\hline & & & & & 花弁 & 雄ずい & その他a) & \\
\hline $5 / 20$ & 開花盛期 & 花 & 202 & $3 \sim 5$ & 0 & 0 & 0 & 0 \\
\hline $5 / 28$ & 開花 終 期 & 花 & 212 & $3 \sim 5$ & 24 & 10 & 176 & 210 \\
\hline $5 / 28$ & 開花 終 期 & 幼果 & 200 & $6 \sim 11$ & - & - & 0 & 0 \\
\hline $6 / 3$ & 幼 果 期 & 幼果 & 200 & $8 \sim 12$ & - & - & 0 & 0 \\
\hline $6 / 10$ & 幼 果 期 & 幼果 & 100 & $13 \sim 18$ & - & - & 0 & 0 \\
\hline $6 / 16$ & 幼 果 期 & 幼果 & 100 & $19 \sim 22$ & - & - & 0 & 0 \\
\hline $7 / 8$ & 幼 果 期 & 幼果 & 100 & $22 \sim 27$ & - & - & 0 & 0 \\
\hline
\end{tabular}

a) 花では雌ずい，子房とがく，幼果では子房とがく．

第 2 表 着色程度の異なる被害果のふ化幼虫数とふ化痕数a)

\begin{tabular}{|c|c|c|c|c|c|c|c|c|c|c|}
\hline \multirow{3}{*}{ 着色程度 } & \multirow{3}{*}{ 品種 } & \multirow{3}{*}{ 調查日 } & \multirow{3}{*}{$\begin{array}{l}\text { 調查 } \\
\text { 果数 }\end{array}$} & \multirow{3}{*}{$\begin{array}{l}\text { ふ化幼虫 } \\
\text { 数／果 }\end{array}$} & \multirow{3}{*}{$\begin{array}{l}\text { ふ化痕を } \\
\text { 認めた果 } \\
\text { 実率 }(\%)\end{array}$} & \multicolumn{4}{|c|}{ ふ化痕数／果 } & \multirow{3}{*}{ 合計 } \\
\hline & & & & & & \multicolumn{2}{|c|}{ 果こう部 } & \multicolumn{2}{|c|}{ 果頂部 } & \\
\hline & & & & & & 果こう側 & 赤道側 & 赤道側 & 果頂側 & \\
\hline 未着色 & 高林 & $5 / 13$ & 54 & $0.26 \mathrm{a}$ & 9.3 & 0 & 0.06 & 0.09 & 0.11 & $0.26 \mathrm{a}$ \\
\hline 4 分 & 興津 & $6 / 16$ & 20 & $0.50 \mathrm{a}$ & 35.0 & 0 & 0.15 & 0.25 & 0.30 & $0.70 \mathrm{a}$ \\
\hline 9 分 & 高林 & $6 / 16$ & 23 & $1.96 \mathrm{~b}$ & 91.3 & 0.39 & 1.04 & 1.04 & 0.61 & $3.08 \mathrm{bc}$ \\
\hline 6 分 & 興津 & $6 / 24$ & 21 & $1.33 \mathrm{~b}$ & 85.7 & 0.29 & 0.52 & 0.62 & 0.95 & $2.38 \mathrm{~b}$ \\
\hline 10 分 & 高林 & $6 / 24$ & 22 & $1.73 \mathrm{~b}$ & 100 & 0.54 & 2.18 & 1.27 & 0.64 & $4.63 \mathrm{c}$ \\
\hline
\end{tabular}

a) 同一欄内の同一文字間にはダンカン多重比較検定 (危険率 $5 \%$ ) による有意差なし.

た。一方, 露地ウンシュウミカン上での成虫の寄生は, 開花開始前には認められなかったが，開花が始まると認 められるようになり, 寄生虫数及び寄生率は, 開花盛期 (花らいの $80 \%$ 程度が開いた時期) から開花終期 (過半 数の花が褐変または落弁した時期) にかけて次第に増加 した。花弁が落下し幼果期に入ると寄生は再び認められ なくなり，幼果には全期間を通して寄生が認められな かった。

開花終期の花に由来する幼果には， 6 月の梅雨期にが く付近から腐敗が発生した。この腐敗はがく付近の果皮 や果こうへ広がった。腐敗の発生した幼果はがくを残し て落果する生理落果とは異なり，樹上で枯れて 7 月下旬 までに全て自然に落下し，10月21日以降に収穫された 果害には本種による被害は認められなかった。

\section{2. 花や幼果からの幼虫小化数}

開花盛期の花から幼虫のふ化は認められなかったが, 開花終期の花から 1 花当り 0.99 頭の幼虫がふ化した。 幼虫は花弁や雄ずいより雌ずい, 子房やがくから多くふ 化した。また, 同時期のトラップへの成虫捕獲数の多少 に関わらず幼果からのふ化幼虫は認められなかった(第 1 表)。

前述の成虫寄生および果実腐敗を合わせて考えると， 成虫は幼果に寄生・産卵しないが, 花の時期に産卵さ
れ，ふ化した幼虫は引き続き幼果に寄生し，加害するも のと推察される。

\section{3. 着色程度の異なる果実からの小化幼蜘とふ化痕 数の差異}

被害果からの幼虫方化数 (第 2 表) は, 果実の着色程 度が高いほど多く, 着色程度 4 分以下と 6 分以上の間 に有意差が認められた。また,一つの果実内では, 着色 程度が低い時期は, 着色の遅い果こう部のふ化痕数が少 なかったが, 着色とともに果害全体にふ化痕が認められ るようになった。

4. ウンシュウミカン幼果に放飼した成虫の生存と 加害

ウンシュウミカン幼果だけを入れた容器に成虫を放飼 した場合は，接種 6 日後までに全ての虫が死亡したが, シキキツの完熟果とウンシュウミカンの幼果を混在させ た容器では, 放飼 4 日後にふ化幼虫が確認され, 放飼 6 日後まで成虫の生存が確認された。ウンシュウミカンの 幼果だけの場合も, シキキツの完熟果とウンシュウミカ ンの幼果を混在させた場合も, ウンシュウミカンの幼果 には摄食痕とふ化痕は認められなかったが, シキキツの 完熟果には両方とも認められた (第 3 表)。

5. 幼虫接種による幼果被害の再現

梅雨期の雨天日に採取して幼虫を接種した幼果では, 
第 3 表 ウンシュウミカンの幼果単独及びシキキツの完熟果を同時に入れた場合の ミカンキイロアザミウマの生存と産卵

\begin{tabular}{|c|c|c|c|c|c|c|c|c|c|c|c|}
\hline \multirow{2}{*}{ 接種日 } & \multicolumn{2}{|c|}{ 接種成虫数 } & \multirow{2}{*}{$\begin{array}{l}\text { 接種 } \\
\text { 品種 }\end{array}$} & \multirow{2}{*}{$\begin{array}{l}\text { 果径 } \\
(\mathrm{mm})\end{array}$} & \multicolumn{4}{|c|}{ 生虫数 (成虫, 幼虫) } & \multirow{2}{*}{$\begin{array}{c}\text { 攝食 } \\
\text { 痕 }\end{array}$} & \multirow{2}{*}{$\begin{array}{l}\text { 末ふ化 } \\
\text { 卵数 }\end{array}$} & \multirow{2}{*}{$\begin{array}{l}\text { 了化 } \\
\text { 痕数 }\end{array}$} \\
\hline & 倠 & 雄 & & & 1日後 & 4日後 & 5 日後 & 6 日後 & & & \\
\hline $7 / 8$ & 2 & 0 & $\begin{array}{l}\text { 杉山 } \\
\text { 温州 }\end{array}$ & $\begin{array}{l}26.0 \\
26.0 \\
\end{array}$ & 2,0 & 1,0 & 1,0 & 0,0 & $\begin{array}{l}\text { 無 } \\
\text { 無 } \\
\end{array}$ & $\begin{array}{l}0 \\
0 \\
\end{array}$ & $\begin{array}{l}0 \\
0 \\
\end{array}$ \\
\hline $7 / 8$ & 4 & 1 & $\begin{array}{l}\text { 杉山 } \\
\text { 温州 }\end{array}$ & $\begin{array}{l}26.5 \\
26.0\end{array}$ & 5,0 & 0,0 & 0,0 & 0,0 & $\begin{array}{l}\text { 無 } \\
\text { 無 }\end{array}$ & $\begin{array}{l}0 \\
0\end{array}$ & $\begin{array}{l}0 \\
0\end{array}$ \\
\hline $7 / 8$ & 4 & 1 & $\begin{array}{l}\text { 杉山 } \\
\text { 温州 } \\
\\
\text { シキ } \\
\text { キツ }\end{array}$ & $\begin{array}{l}24.0 \\
32.0 \\
\\
28.0\end{array}$ & 5,0 & 5,7 & 5,7 & 3,7 & $\begin{array}{l}\text { 無 } \\
\text { 無 } \\
\text { 有 }\end{array}$ & $\begin{array}{l}0 \\
0 \\
0\end{array}$ & $\begin{array}{l}0 \\
0 \\
7\end{array}$ \\
\hline
\end{tabular}

第 4 表 幼虫を接種したウンシュウミカン幼果での腐敗及び椇食痕と付着虫䔬色の確認果数

\begin{tabular}{|c|c|c|c|c|c|c|c|c|c|c|c|}
\hline \multirow{3}{*}{ 接種日 日) $^{\text {a) }}$} & \multirow{3}{*}{$\begin{array}{l}\text { 供試 } \\
\text { 果数 }\end{array}$} & \multirow{3}{*}{$\begin{array}{c}\text { 平均果径 } \\
(\mathrm{mm})\end{array}$} & \multirow{3}{*}{$\begin{array}{c}\text { 幼虫の } \\
\text { 接種 }\end{array}$} & \multicolumn{2}{|c|}{ 腐敗果数 } & \multicolumn{3}{|c|}{ がく内面 } & \multicolumn{3}{|c|}{ 果 皮 } \\
\hline & & & & \multirow{2}{*}{$\begin{array}{c}\text { 接種 } \\
3 \text { 日後 }\end{array}$} & \multirow{2}{*}{$\begin{array}{l}\text { 接種 } \\
7 \text { 日後 }\end{array}$} & \multirow{2}{*}{ 掑食痕 } & \multicolumn{2}{|c|}{ 付着虫䔬色 } & \multirow{2}{*}{ 摃食痕 } & \multicolumn{2}{|c|}{ 付着虫䔬色 } \\
\hline & & & & & & & 淡黄 & 濃緑 & & 淡黄 & 濃緑 \\
\hline \multirow{2}{*}{$6 / 21$} & 3 & 16.3 & 有 & 3 & 3 & - & - & - & - & - & $-b)$ \\
\hline & 3 & 16.3 & 無 & 0 & 0 & 0 & 0 & 0 & 0 & 0 & 0 \\
\hline \multirow{2}{*}{$7 / 19$} & 3 & 24.0 & 有 & 0 & 0 & 3 & 3 & 0 & 3 & 3 & 3 \\
\hline & 3 & 23.3 & 無 & 0 & 0 & 0 & 0 & 0 & 0 & 0 & 0 \\
\hline
\end{tabular}

a) 6 月 21 日は雨天日, 7 月 19 日は晴天日.

b)一は未調查を示す。

接種 3 日後に幼果のがく付近の果皮に腐敗の発生が確認 されたが，無接種では接種 7 日後までに腐敗は発生しな かった。梅雨明け後の晴天日に採取した幼果では, 接種 果のがく内面とがく付近の果皮に前述のような搨食痕が 認められたものの, 接種果, 無接種果とも腐敗は認めら れなかった(第 4 表)。この場合がく内面に付着した虫䔬 は淡黄色の䔬のみだったが, がく付近の果皮に付着した 虫䔬には, 淡黄色の䔬と濃緑色の䔬が混在していた。前 述の果皮色と䔬の色との関係を合わせて考えると，接種 以前に搨食したハウスミカンの淡黄色の色素が, 接種後 最初に定着したがく内面に排出された䔬の色に現われ， 接種後に掑食した幼果の濃緑色の色素が, 移動してきた がく付近の果皮に付着した䔬の色となって現われたもの
と推察される。

\section{6. 幼果の庵敗原因となった菌}

幼果の腐敗部位からカンキツ園に一般に広く分布する 炭そ病菌, フザリウム菌等が分離された(第 5 表)。

\section{考察}

\section{1. 花および幼果に対する寄生特性}

露地栽培では，花らいには寄生せず，開花とともに寄 生が認められるようになり, 寄生虫数及び奇生率は開花 盛期から開花終期にかけて大きく増加した。これは成虫 が花を選好して移動したために，EBELING (1959) がグ レープフルーツで指摘したように早く開花した花が散る と残っている花に移動し，園内の花数が少なくなった開 
花終期には，残っている開花の遅い花に寄生が集中した ためと考えられる。また，開花終期の花からは多くのふ 化幼虫が認められたが，花に混在する幼果からはふ化幼 虫が認められなかったことから，花には産卵するが幼果 には産卵しないと考えられた。

開花終期の花に由来する幼果に認められた果実のがく 付近の腐敗は, 梅雨期の雨天日に採取した幼果への幼虫 接種によって再現された。また, 被害発生ほ場から採取 した幼果の腐敗部から炭そ病菌などカンキツ園に広く分 布している菌が分離されたことから，腐敗は幼虫の摂食 痕から梅雨期の湿度の高い環境で炭そ病菌などの菌が感 染して発生したと考えられた。果実の腐敗ががくの付近 から発生した原因については，幼虫接種試験での色の 違った䔬の分布から判断して最初に攝食したがく内面へ まず菌の感染が起こったためと考えられた。

EBELING (1959) は，カリフォルニアにおける調査で寄 生されたグレープフルーツの幼果は落果すると述べてい る。本試験の結果は, 幼果はいずれは落果するが幼虫の 摂食が梅雨期に果実腐敗を誘導する点でこれと異なっ た。この違いは, 乾燥地帯と梅雨条件下というカンキツ の生育環境の違いによるものと考元られる。

\section{2. 果実への寄生特性}

LUBLINKHOF and FOSTER (1977) によれば,インゲンマ メ上での本種成虫の $20 \sim 30^{\circ} \mathrm{C}$ での生存期間は $57 \sim 28$ 日である。これに対し，ウンシュウミカン幼果では 6 日 後までに全てが死亡したことから，幼果は成虫の飭に適 さないと考えられた。また，一つの果実内では着色の遅 れた部分のふ化痕数が少なく，施設内では着色程度の低 い収穫前 (6 月中旬) より収穫期 (7 月) の果実に多くの 幼虫が認められたことから，本種は着色の進んだ果皮を 選好して産卵すると考えられた。これらを総合すると， 幼虫はウンシュウミカンの幼果・成熟果とも加害可能で あるが，実際には成虫の寄生時期が限定されるので，被 害は成虫の生存が可能になる油胞が黄色になった時期以 降に限られることになる。また, 露地栽培で果実の着色 期に被害が認められなかったのは，この時期が本種の終 息期と一致したためと考えられた。

成熟果への加害の様相について, HUNTER and ULIMAN (1989)は，電子顕微鏡により本種が攝食時に細胞に口吻 を差し込んで内容物を吸入することを明らかにしている が，本試験で果皮に観察された掑食痕（微細な空洞の集 合）はこれとよく一致していた。しかし熟果の被害症状 について EBELING (1959) は, グレープフルーツでシルバ リングの発生を報告しているが, この症状はウンシュウ
ミカンで認められた症状と異なることから，加害するカ ンキツ種によって被害症状が異なる可能性があり被害と 品種の関係については更に検討を要する。

\section{3. 新梢への寄生特性}

EBELING (1959) は，ブドウで本種の寄生による新梢の 屈曲や，新葉の生育阻害から局部的壊死にいたる被害の 発生を報告しているが，ウンシュウミカンでは新梢への 寄生および類似の被害は確認できなかった。したがって 本種はウンシュウミカンの新梢を選好しないと考えられ たが，その理由については更に検討を要する。

\section{4. 防除の必要性}

本試験の結果, 本種がウンシュウミカンの果実を攝食 加害するのは，果実の油胞が黄色になる時期から収穫が 終るまでの期間に限られることが明らかになった。施設 栽培では，この期間が夏で本種の発生期に当るため防除 が必要である。一方, 露地栽培では, この期間が秋で本 種の終息期に当るため被害が発生しないことや, 開花終 期の花に由来する幼果はたとえ健全でも本来摘果作業で 除去されるべき幼果に当るために防除の必要はないと考 えられた。しかし，本種の発生期に熟す日向夏，サマー フレッシュ等のカンキツ類では防除の必要性が生じる可 能性がある。

摘 要

ミカンキイロアザミウマのウンシュウミカンへの寄生 特性と被害の特徵を施設及び露地ほ場の調査と接種試験 によって検討した結果，次のことが明らかになった。本 種は花及び果実に寄生し，花では開花盛期から開花終期 にかけて寄生率が高まり，終期の花からは多くの幼虫子 化が認められた。産卵は花弁及び雄ずいより雌ずい，子 房及びがくに多かった。ふ化幼虫の幼果に対する捸食は がくの内面からがく付近の果面に行われ，この傷から梅 雨期に炭そ病菌等が感染して腐敗が発生した。被害は開 花終期の花に由来する幼果に限って発生し, 被害果は生 理落果しないが7月下旬までに自然落下した。これは通 常管理で摘果される果実に当るため経営には影響しない と考えられた。成虫は幼果には寄生せず，接種した成虫 は生存できなかった。果実への成虫の寄生と摂食が行わ れたのは，果皮の油胞が黄色になった時期から収穫期ま でであった。果皮への産卵は着色した部位を選好して行 われていた。果実の被害は，白いカスリ状の斑点とな り，果皮色と同色の䔬を伴っており，この斑点は果皮表 層にできた微細な空洞の集合であった。新梢には，その 硬化程度に関わらず寄生や被害は認められなかった。 


\section{引用文 献}

BRYAN, D.E. and R.F. SMrTH (1956) The Frankliniella occidentalis complex in California (Thysanoptera: Thripidae). Univ. Calif. Publ. Ent. 10: 359-410.

Ebeling, W. (1959) Subtropical Fruit Pests. California: University of California, $436 \mathrm{p}$

福田 寛・河川利幸・久保田篤男・早瀬 猛 (1991) ミカンキ イロアザミウマの発生と防除。関東病虫研報 $38: 231-233$.

Hunter, W.B. and D.E. Ullman (1989) Analysis of mouthpart movements during feeding of Frankliniella occidentalis (PERGANDE) and $F$. schultzei Твувом (Thysanoptera: Thripidae). Int. J. In- sect Morphol. Embryol. 18 : 161-171.

Lublinkhof, J. and D.E. Foster (1977) Development and reproductive capacity of Frankliniella occidentalis (Thysanoptera: Thripidae) reared at three temperatures. Kan. Ent. Soc. 50 : 311-316.

德永芳雄 (1984) 植物病原菌学, 東京: 博友社, 398 p. 土屋雅利・多々良明夫・池田二三高 (1992) 静岡県におけるミカ ンキイロアザミウマの発生と防除上の問題点. 植物防疫 $46: 437$.

土屋雅利・古橋嘉一 (1993) 新害虫ミカンキイロアザミウマのハ ウスミカンにおける発生と被害. 関東病虫研報 40 : 265268. 